\title{
The Apocalypse of Weeks: Periodization and Tradition-Historical Context
}

\author{
Loren T. Stuckenbruck
}

\section{Introduction}

The organization of time was undoubtedly a central concern in the Apocalypse of Weeks (hereafter, AW). This work is preserved among Enochic writings most fully collected in the Ge'ez Mäṣhafä Henok, or 1 Enoch. As is well known, Aw is split up in the Ge'ez text tradition into two parts that are out of sequence, with the first part in 1 En. 93:1-10 and the second prior to it, in 91:10-17. While the original order was long apparent on source-critical grounds, it was confirmed with the publication of Dead Sea fragments to the text in Aramaic from 4Q212, a manuscript datable to the first century BCE. ${ }^{1}$ Though contiguous to (4Q212) and within (so the Gecez) two other works composed just before the mid-second century BCE (the Epistle of Enoch, 1 En. 92:1-5 + 93:11-105:2 and Exhortation at 91:1-10 + 91:18-19), both the setting and date of AW are by no means secondary; indeed, it may have been composed just prior to the outbreak of the Maccabean revolt (i.e., before 167 BCE) in the wake of the growing socio-political and religious conflict with the Seleucids and Hellenistic reforms taking place in Jerusalem. ${ }^{2}$ If this date holds, then Aw, which antedates both the Animal Apocalypse (1 En. 85-9o) and the Book of Daniel (chs. 7-12), is one of the earliest, if not the earliest "historical" apocalypse of Jewish tradition. As such, and in the context of the present volume's focus on the four kingdoms, it merits a closer look.

While the four beasts in Daniel 7 focus on powers that dominated the Levant from the early-sixth century to the first half of the second century BCE, AW, as the Animal Apocalypse considered history more widely, from the beginning of humankind all the way to the eschaton and even beyond. If one were to imagine how Danielic traditions, whether the book itself or related literature (e.g., the so-called "Pseudo Daniel" texts in 4Q243-245), located themselves within

1 J. T. Milik, The Books of Enoch: Aramaic Fragments from Qumrân Cave 4 (Oxford: Clarendon, 1976), 245-72 (and plates XXI-XXIV). Despite some scholarly debate regarding the sequence of AW in the Aramaic, Milik's reconstruction of the 4 Q212 can be confirmed. See the discussion in Loren T. Stuckenbruck, 1 Enoch 91-108, CEJL (Berlin: Walter de Gruyter, 2007), 50-52.

2 Stuckenbruck, 1 Enoch 91-108, 6o-62 (and bibliography in n. 112). 
a wider scheme of ideal history, then the Enochic texts may provide an initial point of departure. The Apocalypse of Weeks, in turn, no doubt took over existing traditions and, alternatively, played a role in shaping other Second Temple textual tradition that, at the same time, fell heir to the four kingdom scheme (see the brief look at Sib. Or. 4 below). Before making a few observations on the ten-week structuring of time in AW, I would like to offer an outline of the work that in large part covers most of its content as well.

\section{$2 \quad$ Outline and Overview}

An overview of AW is achieved by recounting its self-presentation in the following terms: the period in question (column 1); events associated with that period (column 2-for eras two through six identified in brackets with more conventional designations); and the way these events are characterized (column 3$){ }^{3}$

TABLE 1 Time structures and historiographical frameworks in the Apocalypse of weeks
(1) Era/“Week”
(2) Events
(3) Character

\begin{tabular}{|c|c|c|}
\hline & $(P A S T)$ & \\
\hline ONE (93:3) & Birth of Enoch ( 7 th part) & Justice and righteousness \\
\hline \multirow[t]{5}{*}{ Two (93:4) } & Rise of evil; sprouting of deceit & Evil \\
\hline & The "first end" (Great Flood) & Judgment \\
\hline & A man (Noah) rescued & Deliverance \\
\hline & Increase of iniquity & Evil \\
\hline & Law given for sinners & Expedient law \\
\hline \multirow[t]{2}{*}{ THREE (93:5) } & A man (Abraham) chosen as & Election and righteousness \\
\hline & plant of righteousness & \\
\hline \multirow[t]{5}{*}{ FOUR $(93: 6)$} & Visions of holy and righteous ones & Permanent law \\
\hline & Law given for every generation & \\
\hline & (Torah) & \\
\hline & Enclosure made for them & \\
\hline & (tabernacle) & \\
\hline \multirow[t]{3}{*}{ FIVE (93:7) } & House of glory and royalty/ & Permanent temple A \\
\hline & kingdom built (pass. div.) for & \\
\hline & eternity (Temple) & \\
\hline
\end{tabular}

3 Adapted from Stuckenbruck, 1 Enoch 91-108, 57-58. 
TABLE 1 Time structures and historiographical frameworks (cont.)
(1) Era/“Week”
(2) Events
(3) Character

$\operatorname{SIX}(93: 8)$

The blind fall away from wisdom Evil

A man (Elijah) ascends

Deliverance

House of royalty/kingdom burned Evil

The chosen root scattered

Evil

\section{(PAST-PRESENT)}

$\begin{array}{lll}\text { SEVEN A }(93: 9-10) & \text { Rise of wicked generation } & \text { Evil } \\ & \text { Election of the chosen righ- } & \text { Election and righteousness } \\ & \text { teous from eternal plant of } & \\ & \text { righteousness } & \\ & \text { Sevenfold instruction on the } \\ & \text { entire creation } \\ & (\text { FUTURE })\end{array}$

(FUTURE)

SEVEN B (91:11) Uprooting of oppression Judgment

Destruction of sinners

EIGHT (91:12-13) Judgment on oppressors and Judgment

sinners by the righteous

Righteous obtain wealth/_ Reward

possessions

Temple of the Great King built in Permanent temple B glory forever

NINE (91:14) Revelation of righteous judgment Judgment

to the whole world

Works of the wicked recorded for

destruction

All people look to the way of Righteousness

righteousness

\begin{tabular}{|c|c|c|}
\hline \multirow[t]{2}{*}{$\operatorname{TEN}\left(91: 15^{-16}\right)$} & $\begin{array}{l}\text { Eternal judgment ( } 7 \text { th part) } \\
\text { Judgment against watchers and } \\
\text { among angels }\end{array}$ & Permanent judgment \\
\hline & $\begin{array}{l}\text { Disappearance of the first heaven } \\
\text { Creation of a new heaven } \\
\text { Every heavenly power shines } \\
\text { sevenfold forever }\end{array}$ & $\begin{array}{l}\text { Permanent destruction } \\
\text { New cosmos }\end{array}$ \\
\hline WEEKS WITHOUT & Goodness and righteousness & Permanent cosmic order \\
\hline NUMBER (93:17) & Memory of sin erased & \\
\hline
\end{tabular}


The time covered in AW is comprehensive: it embraces events spanning from the primordial era before the great flood all the way up to and even beyond the eschatological future. The putative author, Enoch, is made to tell the story, most of which is presented as future from his perspective. The measured part of history is divided into ten "weeks." The term, which draws attention to the principled significance of the number seven, denotes predetermined periods of time, whether or not they are to be understood as equal in some way. ${ }^{4}$ Within this scheme, AW is highly selective in choosing from a number of larger pools of possibilities. Its brief descriptions of events to occur in each week mark out in one or, at most, two sentences one or more occurrences that are deemed to be either bad or good and, thus, are implicitly exhortational. The events, which reflect matters of particular concern to the writer, reflect something of what the writer regards as the ideal community, as indicated by the nomenclature "plant of righteousness" in weeks three and seven. The text assumes an audience's knowledge of more events than are actually narrated, and so underscores the sacredness of those that are included. For example, while there is no mention of the creation story in the first week, passing references to the created order in weeks seven (93:10) and ten (91:16) presuppose the creation account of which implied hearers and readers would already be aware. The selectivity of the narrative is also enhanced by the account's twofold reference to a "seventh" part in weeks one (93:3) and ten (91:15). These parts of those weeks - that is, not others which remain untold - are of particular import, while the text may assume that all ten periods can be subdivided in this way. This zeroing into smaller units is surely deliberate: the selection of Enoch's birth in 1 En. 93:3 locates the fictive author near the beginning of the grand narrative of redemptive history, while the focus on "eternal judgment" in the seventh part of week ten brings this sacred history to a conclusion that embraces the entire cosmos.

4 Cf. Klaus Koch, "Von der Sabbatstruktur der Geschichte: die sogenannte Zehn-WochenApokalypse (1Hen 93,1-10; 91,11-17) und das Ringen um die alttestamentlichen Chronologien im späten Israelitentum," ZAW 95 (1983): 403-30 (here, 429-30), who has argued that each of the weeks in this text consist of equally divided 490-year periods; and similarly, Devorah Dimant, "The Seventy Weeks Chronology (Dan. 9:24-27) in the Light of New Qumranic Texts," in A. S. van der Woude, The Book of Daniel in the Light of New Findings, BETL 106 (Leuven: Leuven University Press, 1993), 57-76 (esp. 66-67). 


\section{The Ten-Week Scheme and Its Immediate Tradition-Historical Context}

The Apocalypse of Weeks is not the only section within 1 Enoch, as we received it in the Ge'ez text tradition, that covers sacred history. Prima facie, the Animal Vision (1 En. 85:1-90:42) does the same, though it (a) goes into more detail, (b) is dominated by zoomorphic images, (c) does not partition the entire story into numbered eras, and (d) makes no mention of an unlimited period following the end. Beyond this, the Animal Vision devotes far more attention to the activities of oppressive regimes of inimical powers, both cosmic (e.g., the 70 disciplining "shepherds" in 89:59-77, and 90:1, 19, 22, 25) and political (e.g., various wild animals, prominently eagles in 90:1-18). Finally, the Animal Vision is much less explicit than AW about its structure; it is left to an audience to infer more precisely when the angelic figures are active in the narrative and, coordinated with them, when socio-religious and political circumstances take place. It remains that no scheme within the narrative is readily subject to a numbered sequence. ${ }^{5}$ Nevertheless, and despite the different lengths of the AW and the Animal Vision, there are a number of overlaps in theme and content $^{6}{ }^{6}$ though these in turn expose several very real differences between the two works. ${ }^{7}$

5 The seventy shepherds are not introduced until the time of the exile (1 En. 89:59), so that the entire account is only covered from them until the time of eschatological judgment. In any case, they are correlated with punishing activities (89:60) and represent a period of time as a group of thirty-five, each of whom act singly in a time assigned to them (90:1-2a); cf. Antti Laato, "The Chronology in the Animal Apocalypse of 1 Enoch 85-90," JSP 26 (2016): 3-19.

6 For a listing of comparable motifs in the two works-with references to parallels in Damascus Document (CD 2-6), Jubilees (esp. 23:12-31), Community Rule (1QS 8-9), and Daniel 11:14see George W. E. Nickelsburg, 1 Enoch 1, Hermeneia (Minneapolis: Fortress Press, 2001), 398-40o.

7 A number of the events and characters mentioned in AW are not found in the Animal Vision: e.g., in AW there is no messianic figure, nor are there references in the latter to the birth of Enoch, the law, a figure equivalent to Elijah, and weeks without end. One wonders, then, whether the almost contemporary Enochic authors would have recognized one another as legitimate heirs to the Enochic tradition. This possibility, taking 1 En. 104:10-12 as a point of departure, has not been adequately considered thus far and goes beyond my comments in Stuckenbruck, 1 Enoch 91-108, 582-6o5; and Loren T. Stuckenbruck, "Reflections on Sources Behind the Epistle of Enoch and the Significance of 1 Enoch 104:9-13 for the Reception of Enochic Tradition," in A Teacher for All Generations: Essays in Honor of James C. VanderKam, ed. Eric F. Mason et al., JSJS 153/2 (Leiden: Brill, 2012), 2:705-14 (here 713). 
As the outline presented above indicates, the most important numbers in AW are ten and seven, ${ }^{8}$ with the latter implied by the repeated use of "week" as the overriding designation for each era. The final era, which is neither designated as an "eleventh" nor constitutes a measurable era, is simply designated "weeks without number" (91:17). While this concluding phase is portrayed as numberless and expresses a certain infinitude, the continued description of it in terms of "weeks" suggests that the importance of the number "seven," as endemic to the created order, does not disappear.

\subsection{Parallels to the Ten-Fold Scheme of History in the Apocalypse of Weeks}

John Collins, ${ }^{9}$ noting a possible derivation from "the Persian idea of the millennium,"10 mentions a series of analogous schemes in Second Temple Jewish sources, among which it is, in my view, difficult to draw anything more than a loose connection. It remains of interest, however, that this ten-fold periodization does not stand alone, and could readily be combined with others. One collection of sources in which this occurs, is the Sibylline Oracles books $1-2\left(1.65^{-124}\right.$ and $\left.283^{-323} ; 2.6-38\right)$ and 4 (49-101). The vestiges of the ten generations in Sibylline Oracles books 1 and 2, a Second Temple composition reworked by later Christian interpolators, conspicuously differ from the scheme of AW, even though they prima facie also assign a series of events to the eschaton. For example, the figure of Noah is assigned to the fifth era (in AW, Noah is in the second week), and eschatological events are saved for the tenth (whereas in AW, they begin during the seventh). In Sibylline Oracles book 4, ten eras are combined with the four kingdom scheme: they are divided into six generations under Assyrian rule (4.49-53), with two following under the Medes (54-64), one under the Persians (65-87), and a final tenth generation under the Greek or Macedonians (88-101). The writer's present, which may be assigned to the aftermath of the destruction of the Jerusalem Temple in $7 \mathrm{O} \mathrm{CE}$, correlates to the time of the Roman Empire, which lies outside the ten-fold

8 There is no hint of a four kingdom scheme in Aw. Nickelsburg, 1 Enoch 1, 440, states that "the author of the Apocalypse of Weeks stands in a firmly established and broad apocalyptic tradition of structuring history using the numbers seven and ten." While vestiges of the combination occur in several apocalyptic texts, this does not apply to the passages from Sibylline Oracles 1-2 and 4 noted below.

9 John J. Collins, The Apocalyptic Imagination, 3rd ed. (Grand Rapids: Eerdmans, 2016), $80-81$.

10 A ten-fold division of history is preserved throughout the Bhaman Yasht (Zand-ī Vohüman Yasn); cf. John J. Collins, "Sibylline Oracles," отP, ed. James H. Charlesworth (Garden City, NY: Doubleday, 1983), 1:332 and 345; and the earlier study by David Flusser, "The Four Empires in the Fourth Sybil and in the Book of Daniel," IOS 2 (1972): 148-75. 
scheme. ${ }^{11}$ This scheme applies to the past up until the present, and anticipates an eschatological judgment heralded by the volcanic eruption of Mount Vesuvius. Although the inclusion of the Roman Empire suggests the adaptation of an older four kingdom ten generation scheme, there is no obvious influence from either Daniel or Aw which, unlike book 4, envision the establishment of God's rule. In addition, whereas in Daniel 7 the first kingdom is Babylon (not Assyria) and the divine kingdom follows the fourth kingdom (without reference to a ten-era scheme), in AW, in which there is no four kingdom scheme, the eschatological reign of God is placed within the eighth week. ${ }^{12}$

Another, though very fragmentary source is the so-called Pesher of the Periods preserved in 4Q180-181. ${ }^{13}$ The number "ten" occurs in 4Q180 12 where the text states, "un]til he begat Isaac; ten $h$ [" (cf. the small parallel 4Q181 21 , "he begat] Isaac"). This uncertain reference to "ten" may have in mind a period of ten generations between Noah (who is unnamed) and Abraham, who is clearly the progenitor of Isaac. Perhaps significant is the possible mention of "seventy weeks" in 4Q181 $23^{14}$ — this period would refer to the time during which 'Asa'el and the angels led Israel astray' - which may, as implied in AW, reflect a combination of ten and seventy within the periodized scheme. The tenth era in $4 \mathrm{Q} 18 \mathrm{O}-181$, if it is to be understood as such, then, and very much unlike AW, pertains to an era of the writer's remote past.

11QMelchizedek (11Q13) ii 7-8 seems more relevant. The text, having mentioned a ninth jubilee, refers to a "da]y of atonement" that will occur at "the $\mathrm{e}$ [nd of] the tenth [ju]bilee." Again, there is a combination of an overarching number of ten which, as a jubilee, is further divisible into forty-nine, a multiple of seven. In addition, as in $\mathrm{AW}$, the tenth period/jubilee is eschatological, ${ }^{15}$ though in AW the eschatological period already begins in the middle of week seven. In this respect, it is interesting that the writer behind AW apportions the eschatological future differently; it does not invest the entire eschatological future in week seven, but extends it through and beyond a tenth week.

11 Cf. John J. Collins, Apocalypse, Prophecy, and Pseudepigraphy: On Jewish Apocalyptic Literature (Grand Rapids: Eerdmans, 2015), 108-26 (here 118-22).

12 Therefore, it is difficult to posit that Sib. Or. 4 has taken over its scheme from AW in any direct way.

13 Cf. Milik, The Books of Enoch, 248-5o, who plausibly argued that these manuscript fragments belong to the same work, though doubt on assuming this was questioned by Devorah Dimant, "The 'Pesher on the Periods' (4Q180) and 4Q181," in IOS 9 (1979): 77-102.

14 The text (השביע שבעים could mean either "he satisfied (Israel) seventy times" or "(Israel) seventy weeks."

15 Moreover, "the last age" referred to in Vergil's Eclogae 4.4 is interpreted by a later commentary of Servius (4OO CE) as "the tenth." 
3.1.1

The Structural Significance of "Seven" in the Ten-Week Framework The number "seven," including its multiples, is significant in AW in at least three ways. First, the text of Aw implies the number seventy. The scheme of ten weeks, as mentioned, is predicated on the more detailed scheme of each week being divided into a further seven: ten weeks times seven parts in each, amounting to seventy parts (so week one part seven, "Enoch's birth" [93:3]; week ten part seven, "the eternal judgment" [91:15]). The influence behind such a seventyperiod scheme is unknown, nor can it be inferred that these sub-eras are assumed in the text to have been of equal duration. ${ }^{16}$ It is possible that AW is receiving and interpreting the Book of Watchers at 1 En. 10:12, which mentions that the rebellious angels are to be bound "for seventy generations,"17 a period which spans from the time of the Flood when the rebellious angels are bound to the final judgment. However, these seventy generations correspond to AW weeks two (beginning with "the first end") through ten (when the watchers are judged). There is, then, not a precise fit between the two texts, since Aw covers the antediluvian period as well.

Several writings in the Hebrew Bible also show an interest in the number seventy for the structuring of time. Well known is the reference in Jeremiah to "seventy years" as the period of duration for the Babylonian exile (Jer 25:1112; 29:10). Similarly, in Zech 1:12-17 a duration of seventy years is applied to the Temple's ruined state (cf. also Zech 7:5), with the text adding that after this the Temple will be rebuilt (Zech 1:16). Seventy years are also mentioned in ${ }_{2} \mathrm{Chr} 36: 21$, though there they are referred to as "seventy years of rest" in the land. Thus the Jeremianic prophecy that focuses on the exile from the land and the Chronicler's emphasis on rest in the land stand at odds.

In Daniel chapter 9, which was composed perhaps just a few years after AW, the seventy years of Jeremiah (Dan 9:2) are explicitly reinterpreted as seventy "weeks of years" (Dan 9:24). Yet, though the prophecy in Daniel 9 expressly appeals to Jeremiah's seventy years, Michael Segal has questioned whether the seventy weeks of years (i.e., 490) include Jeremiah's seventy or, in fact, begin with the imagined time of Daniel himself, just prior to the edict of Cyrus. ${ }^{18}$ If Daniel 9 has in view 490 years that extend from the exile, beginning in $586 \mathrm{BCE}$,

16 See $n .2$ above. On the periodization of history into fixed times in Persian systems, Daniel 2 and 7, Hesiod's Theogony and Works and Days and Berossos, as noted, for example, by Martin Hengel, Judaism and Hellenism: Studies in Their Encounter in Palestine during the Early Hellenistic Period, trans. John Bowden (Philadelphia: Fortress Press, 1974), 1:181-96.

17 Collins, The Apocalyptic Imagination, 81.

18 Michael Segal, Dreams, Riddles, and Visions: Textual, Contextual, and Intertextual Approaches to the Book of Daniel, BZAW 455 (Berlin: Walter de Gruyter, 2016), 155-79. As Segal reconstructs, the "seven weeks" (49 years following Daniel's prophecy) lead from the 
then the writer's present, which corresponded to the end of the sixty-second week, is some 434 years later, with him anticipating a further seven times seven years (49; cf. Dan 9:25). However, if the 490 years begin with the putative time of Daniel, then the sixty-second week calculates to somewhere around the turn of the first century BCE. It seems clear that neither construal of Danielic chronology has had an impact on that of AW. Nevertheless, similar to Daniel, $\mathrm{AW}$ applies a scheme that appeals to the past in order to project upon the future, a future that, from both real authors' perspective, leaves a period of time for anticipated divine interventions to take place.

In the other almost contemporary Enochic composition, the Animal Vision, as mentioned above, the number seventy denotes shepherds appointed to rule from the precarious time of exile (associated with Jehoiakim) until the eschaton (cf. 1 En. 89:59-64). It is unclear, though, whether the Animal Vision implies a division into seventy time-units, because its periodization of time correlates more readily to a four-fold scheme of successive phases: (1) the exile (1 En. 89:65-72a), (2) Persian rule (89:72b-9o:1), (3) Ptolemaic rule (9o:2-5), and (4) the Seleucid rule of the writer's present $(90: 6-12) \cdot{ }^{19}$ Here, the Animal Vision, in weaving an implicit four kingdom pattern into the period of seventy shepherds, ends up with an asymmetrical scheme that is less unambiguously set out than that of Aw.

It is also possible that the "seventy weeks" in the Pesher on the Periods (see 4 Q181 23 3) are 490 years of straying that, similar to AW at 1 En. 93:2, are "engraved on the [heavenly/eternal] tablets" (so 4 Q18o 11,3$).{ }^{20}$ If the smaller divisions of time of ten periods within the seventy weeks consist of ten jubilees each, then the periods of forty-nine years can be integrated into the seventy weeks' scheme. Such a confluence of ten and seventy would compare to $\mathrm{AW}$, though the way it is worked out is independent, with AW not apparently assigning a definite and consistent period of years to each "week."21 While

putative time of Daniel's prophecy until the advent of an "anointed prince," who can be associated with Nehemiah and his activities.

19 See n. 5 above and, further, Patrick A. Tiller, A Commentary on the Animal Apocalypse of 1 Enoch, EJL 4 (Atlanta: Scholars Press, 1993), 324-57.

20 This only works under the assumption that $4 \mathrm{Q} 180$ and $4 \mathrm{Q} 181$ are manuscripts preserving the same work. See bibliography in $\mathrm{n} .13$ above.

21 Contra John Sietze Bergsma, The Jubilees from Leviticus to Qumran: A History of Interpretation, VTSup 115 (Leiden: Brill, 2007), 238-42, drawing on Koch, "Von der Sabbatstruktur der Geschichte," 403-430; cf. Nickelsburg, 1 Enoch, 440 (such for the first seven weeks). The conforming of the weeks to the same periods of time seems, however, forced; cf. James C. VanderKam, Calendars in the Dead Sea Scrolls, LDss (London: Routledge, 1998), 99: "the author does not assign a uniform length of time to each of his weeks, since they seem to cover differing numbers of years in the biblical story." 
structurally analogous, the comparison is superficial; the scheme inferred from the very fragmentary $4 \mathrm{Q}_{180}$ and $4 \mathrm{Q}_{181}$, to the degree that it can be thought as such, covers a series of much shorter ten-fold durations. In addition, a scheme of ten is fit into a larger framework of "weeks," while in Aw it is a scheme of seven parts that is fit into the larger framework of (ten) "weeks." It is this reading of 490 years as a time of straying in $4 \mathrm{Q}_{18} \mathrm{o}$ with $4 \mathrm{Q}_{1} 81$ that fits well in relation to frameworks found in other Hebrew texts among the Dead Sea Scrolls, ${ }^{22}$ while AW remains distinct.

A final text to consider is the Damascus Document. Similar to Daniel 9, it has been thought to draw on a 490-year scheme (of seventy weeks of years). ${ }^{23}$ In the Damascus Document, however, reference to such an era, which clearly begins with the start of the exile (4Q266 i 6-7), is at best only implicit. It relies on the sum of eras expressly mentioned in the text (390 years, ${ }^{24}$ plus twenty years of "groping for the way,"25 plus a period of the Teacher of Righteousness's activity), along with a further "forty years" following the Teacher's death to the destruction of those allied with the Man of the Lie (CD в 20:15). It is only if the period of the Teacher's activity is estimated at forty years that the periods add up to 49 .

While a purported 490-year scheme cannot be said to apply to periodization within AW as a whole, a correspondence may be inferred in a more limited sense. Apocalypse of Weeks may presuppose a 490-year scheme within (i.e.,

22 Perhaps closer to Pesher on the Periods are two further texts. One is the so-called Apocryphon of Jeremiah ( $\left.4 \mathrm{Q}_{3} 83^{-}-384,385 \mathrm{a}-\mathrm{b}, 387 \mathrm{~b}, 389 \mathrm{a}\right)$, which refers to "ten jubilees of years" (ten times forty-nine, i.e., 490 years) as a period characterized by walking "in madness, blindness, and confusion" (4Q387b 2 ii $3-4 / / 4 Q_{3} 85$ a 4 1). The other text is $4 Q_{39}$ o, designated Pseudo Moses by Devorah Dimant, "The Seventy Weeks Chronology," 57-76. This text appears to subdivide a scheme of 490 years into four periods, similar to the Animal Vision reviewed above. These periods seem to derive from references in 4 Q39o to (1) seventy years of waywardness during the exile by the Aaronic priesthood ( $12-3)$; (2) a period lasting until the seventh jubilee (343 years) after the destruction of the First Temple (1 7-8); (3) seven (i.e., a week of) years during which the priesthood forgot "the statute," "the festival," "the Sabbath," and "the covenant," when as a result the Jews were handed over to persecution by Antiochus (1 8, 2 i 4); and (4) seventy years of Hasmonean rule associated with "the angels of Mastema" (2 i 6-7). On these 490-year and related schemes, see Cana Werman, "Epochs and End-Time: The 49o-Year Scheme in Second Temple Literature," DSD 13 (2006): 229-55.

23 See Hanan Eshel, Exploring the Dead Sea Scrolls: Archaeology and the Literature of the Qumran Caves, ed. Shani Tzoref and Barnea Levi Selavan, JAJSup 18 (Göttingen: Vandenhoeck \& Ruprecht, 2015), 53-6o (with bibliography on 53 n. 34), who admits that the influence of the 490-year chronology in the Damascus Document is "speculative."

24 Cf. the interpretation of 390 days as years in Ezek 4:5, from which the number in the Damascus Document in CD 1:5-6 (called "the era of wrath") is derived.

25 CD 1:9-10 // 4Q266 2 i 13. 
for part of) the seventh week (1 En. 93:9-10), which begins with the exile (so 1 En. 93:8) and extends into and just beyond the text's present. That, in turn, would not be far off from the way Daniel 9 has applied the scheme (i.e., if the text construes the period with the beginning of the exile), with the present of the real author coming during and towards the end of such a period.

\subsubsection{The Number "Seven" as a Fulcrum Figure in Enochic Tradition}

Second, the number seven is significant as an ordinal for the pivotal period in the sacred history: the seventh week. Although "Enoch" is fictively used to "predict" the entire history following week one, the writer attributes events until the middle of week seven to his own past, while describing events future to his time from the middle of the seventh and on. Week seven marks the crucial transition from recent past to present to imminent future, from the rise of a "wicked generation" (1 En. 93:9) to the election of "the chosen righteous ones" (93:10) to an imminent destruction of sinners by the sword (91:11). This week receives the lengthiest treatment in the work and also correlates to the writer's time, when evil and revelation collide, with those having the latter coming into a position of exercising retributive justice.

\subsubsection{Figures of "Seven" and the Space between Present and Future}

Third, the number seven occurs twice in the term "sevenfold," as found in weeks seven and ten. The expression is related to conditions in the real author's present and ultimate future. The text situates itself in a time when a special disclosure has and is taking place. This disclosure, or better, revelatory knowledge concerns "the whole of his (God's) creation." Significantly, it has its foundation in the past, beginning with the election of Abraham as the "plant of righteousness" in week three (1 En. 93:4), and anticipates the final salvific state of the cosmos when "every power of the heavens will shine sevenfold forever" (91:16). Those to whom the instruction is given are described in terms reminiscent of Abraham, "the chosen plant of righteousness," though with even more emphatic language: according to the Ge'ez version, ${ }^{26}$ "there will be chosen the chosen righteous ones from the eternal plant of righteousness" (93:10), who are no doubt a select group of Jews comprising a matrix within which and out of which the righteous will ultimately be identified. ${ }^{27}$ While the "eternal plant of righteousness" refers to the larger socio-religious matrix that derives from and reaches back to Abraham (Israel at large), the specially chosen ones denote a

26 The manuscript tradition is fairly stable at this point, with the textual variants not departing much from this sense.

27 It is not certain that the text reflects a narrowly formed community. 
more narrowly defined group that, in principle, remains an "open" community to whom revelation is being made available. The content of the revelation is vague; in place of "concerning the whole of his creation" in the Ge'ez version, the only slightly restored text in the Aramaic $\left(4 \mathrm{QEn}^{\mathrm{g}}\right.$ [4Q212] 1 iv 12-13) reads: "c[hosen one $] \mathrm{s}[\mathrm{w}] \mathrm{ill}$ be chosen as witnesses of truth from the etern[al] pl[ant of] truth/righteousness, to whom sevenf[old] wisdom and knowledge will be giv[e]n." ${ }^{28}$ The seven-fold knowledge denotes the complete sufficiency of revelation for the elect community and, though not yet fully implemented, anticipates the reversal from wickedness narrated in the second part of the seventh week when the wicked will be punished. The "seven-fold" shining in week ten thus describes the cosmic outcome of this revelation, with judgment occurring in reverse order: once the eternal judgment has been executed, the heavenly bodies will shine forever (1 En. 91:15-16).

The periodization of Aw thus has much in common with schemes found in other Second Temple literature. However, it remains distinct in the way it combines the ideal numbers of ten and seven (and its derivatives), so that it is difficult to speak of traditions that have either influenced Aw directly or have been influenced by it. At the same time, the way AW relates the real author's present to events of the recent past as a time of revelation reflects a wider pattern not uncommon to some Jewish apocalyptic texts. This claim leads to a final reflection immediately below.

One may close with a brief comparison between the seventh week in AW, the Animal Vision, and the four kingdoms of Daniel 7, as the time of these writings are roughly contemporary (composed within a period of ten years of one another) and, taken together, illustrate a nexus of ideas. In some sense, the Animal Vision, with its integration of an implied four kingdom scheme (1 En. 89:65-90:12), encased within a period covered by the seventy shepherds

28 The revelation of knowledge or insight in the present as a prelude to the future is similarly found in Dan 12:3: "those who instruct" (maskilim) and "those who make many righteous" (mașdiqe ha-rabim) in the present are, together with those they lead ("the many"), will be rewarded as they "shine in the shining of the sky" and become "as stars for eternity" (cf. the confluence of similar themes in the Epistle of Enoch at 1 En. 104-105). See similarly Musar le-Mevin, in which God has already opened "insight" for the one being instructed (presumably as is also the case for his other instructors and the instructor of the text), with the "eternal planting" applying to the community of elect who are aligned with "holy ones" in whose inheritance they possibly share (4Q418 811-14). 
(89:51-90:27), may be regarded as an intermediary between the book of Daniel (in which the four kingdoms, presented as beasts, are explicit) and AW (in which time is covered more comprehensively). What remains comparable in all three, however, is these writings' inclusion of the period extending from the beginning of the exile until the time of composition and into the imminent future. The Animal Vision covers this period with the seventy shepherds and the mention of four oppressive powers, and it is during the last rule that the eyes of the sheep began to be opened (1 En. 90:9-10), and a form of religious resistance takes hold that sets into motion events that the text believes will lead to divine judgment in the near future. Daniel 7 covers this period in two separate segments: in one, four kingdoms are described as beasts $(7: 1-8,17,19-21$, 23-25) and, while the depiction of the first three implies conflicts with Israel, it is with the fourth, arising during the time Daniel 7 was composed, that the clash reaches its zenith, one that is already underway. Here, the writer of the Danielic Aramaic text presupposes the contemporary existence of "holy ones" in Israel $(7: 18,21,27)$ and anticipates divine judgment against the fourth kingdom (and its ruler; 7:26-27). In AW, such interests are in play, but seem much more focused on the internal politics among Jewish communities of Judea and beyond. If AW is read in tandem with the Epistle of Enoch (cf. 1 En. 97:3-4; 105:12-15), AW applies "sinners" as much, if not more, to other Jews who are complicit or associate themselves with the oppressive activities of non-Jewish rule as it does to those powers themselves (while Daniel and the Animal Vision focus on the oppressiveness of foreign rule). ${ }^{29}$

With regard to the present, all three writings situate themselves in a time towards the end of a critical period, not only because that period is depicted as a crisis (rise of evil, persecution, military conflict), but also because in the present, at least for the writers, a definable community - the receptacle of divine activity - is given to play a key role. In the Animal Vision and AW, this community has already been subject to revelation ("their eyes were opened" in the former (1 En. 90:9-10) and "knowledge and wisdom about the whole of creation" in the latter (93:10), while in Daniel the ideal community is simply referred to as "the holy ones of the Most High," against whom the horn (kingdom) of the fourth beast kingdom prevails (Dan 7:21). In other words, even though the seventh week in AW is not explicitly broken down into subunits per se, its correspondence to the period covered by the four kingdoms of Daniel 7 and the Animal Vision, demonstrates that the ideal righteous community of the present stands at the pinnacle of the calculated period of time,

29 On the profile of "sinners" in the Epistle and AW, see Stuckenbruck, 1 Enoch 91-108, 64-65 and 191-204. 
poised to embrace a future in which the inaugurated salvific and revelatory activity of God on their behalf will manifest itself in full justice with retribution and reward. Thus, rather than being overwhelmed by a certain hopelessness in the face of oppressive powers (whether political or religious), these writings, composed between just prior to and during the Maccabean war, found reassurance in the establishment of a religious community that will culminate in eschatological judgment.

\section{Bibliography}

Bergsma, John Sietze. The Jubilees from Leviticus to Qumran: A History of Interpretation. VTSup 115. Leiden: Brill, 2007.

Collins, John J. "Sibylline Oracles." Pages 317-472 in vol. 1 of отP. Edited by James H. Charlesworth. Garden City, NY: Doubleday, 1983.

Collins, John J. Apocalypse, Prophecy, and Pseudepigraphy: On Jewish Apocalyptic Literature. Grand Rapids: Eerdmans, 2015.

Collins, John J. The Apocalyptic Imagination. 3rd ed. Grand Rapids: Eerdmans, 2016.

Dimant, Devorah. "The 'Pesher on the Periods' (4Q180) and 4Q181." Ios 9 (1979): 77-102.

Dimant, Devorah. "The Seventy Weeks Chronology (Dan. 9:24-27) in the Light of New Qumranic Texts." Pages 57-76 in The Book of Daniel in the Light of New Findings. Edited by A. S. van der Woude. BETL 106. Leuven: Leuven University Press, 1993.

Eshel, Hanan. Exploring the Dead Sea Scrolls: Archaeology and the Literature of the Qumran Caves. Edited by Shani Tzoref and Barnea Levi Selavan. JAJSup 18. Göttingen: Vandenhoeck \& Ruprecht, 2015.

Flusser, David. "The Four Empires in the Fourth Sybil and in the Book of Daniel." IOS 2 (1972): 148-75.

Hengel, Martin. Judaism and Hellenism: Studies in Their Encounter in Palestine during the Early Hellenistic Period. Translated by John Bowden. Philadelphia: Fortress Press, 1974.

Koch, Klaus. "Von der Sabbatstruktur der Geschichte: die sogenannte Zehn-WochenApokalypse (1Hen 93,1-10; 91,11-17) und das Ringen um die alttestamentlichen Chronologien im späten Israelitentum." ZAW 95 (1983): 403-30.

Laato, Antti. "The Chronology in the Animal Apocalypse of 1 Enoch 85-9o." JSP 26 (2016): $3^{-19}$.

Milik, J. T. The Books of Enoch: Aramaic Fragments from Qumrân Cave 4. Oxford: Clarendon, 1976.

Nickelsburg, George W. E. 1 Enoch 1. Hermeneia. Minneapolis: Fortress Press, 2001.

Segal, Michael. Dreams, Riddles, and Visions: Textual, Contextual, and Intertextual Approaches to the Book of Daniel. BZAW 455. Berlin: Walter de Gruyter, 2016. 
Stuckenbruck, Loren T. 1 Enoch 91-108. CEJL. Berlin: Walter de Gruyter, 2007.

Stuckenbruck, Loren T. "Reflections on Sources Behind the Epistle of Enoch and the Significance of 1 Enoch 104:9-13 for the Reception of Enochic Tradition." Pages 70514 in A Teacher for All Generations: Essays in Honor of James C. VanderKam. Edited by Eric F. Mason, Kelley Coblentz Bautch, Angela Kim Harkins, and Daniel A. Machiela. JSJS 153/2. Leiden: Brill, 2012.

Tiller, Patrick A. A Commentary on the Animal Apocalypse of 1 Enoch. EJL 4. Atlanta: Scholars Press, 1993.

VanderKam, James C. Calendars in the Dead Sea Scrolls. LDss. London: Routledge, 1998. Werman, Cana. "Epochs and End-Time: The 49o-Year Scheme in Second Temple Literature." DSD 13 (2006): 229-55. 